\title{
Implementasi Literasi dalam Pembelajaran Membaca Berbasis Cerita Rakyat Bengkulu pada Siswa Kelas Iv SD IT Al-Qiswah Bengkulu
}

Chindytia

Program Magister Pendidikan Dasar Universitas Bengkulu. chindytia3@gmail.com

\section{Agus Susanta}

Program Magister Pendidikan Dasar Universitas Bengkulu.

\section{Abdul Muktadir}

Program Magister Pendidikan Dasar Universitas Bengkulu.

\begin{abstract}
Penelitian ini bertujuan untuk mengetahui implementasi literasi pada pembelajaran membaca berbasis cerita rakyat Bengkulu pada tahap pembiasaan, pengembangan dan pembelajaran membaca di kelas IV SD IT AL-Qiswah Bengkulu. Penelitian ini merupakan penelitian kualitatif dengan jenis metode deskriptif yang dilakukan di SD IT AL-Qiswah Bengkulu. Pengumpulan data yang digunakan dalam penelitian ini adalah observasi, wawancara dan dokumentasi. Analisis data digunakan untuk menganalisa implikasi gerakan literasi membaca melalui reduksi data, penyajian data, dan penarikan kesimpulan. Hasil penelitian menunjukkan bahwa (1) implementasi literasi membaca berbasis cerita rakyat Bengkulu pada tahap pembiasaan yakni menumbuhkan minat baca melalui 15 menit membaca buku non pelajaran cerita rakyat Bengkulu (2) implementasi literasi membaca berbasis cerita rakyat Bengkulu pada tahap pengembangan guru memberikan simulasi tentang isi dan memberikan pemahaman mengenai isi bacaan cerita rakyat Bengkulu (3) implementasi literasi membaca berbasis cerita rakyat Bengkulu pada tahap pembelajaran yakni terbiasanya penggunaan lingkungan akademik, fisik, sosial dan afektif untuk literasi membaca cerita rakyat Bengkulu.
\end{abstract}

Kata Kunci: Literasi, Membaca, Cerita Rakyat Bengkulu

\section{Pendahuluan}

Di Era Globalisasi saat ini, banyak hal yang memudahkan manusia dalam kehidupan sehari-hari. Kebutuhan akan apapun akan mudah terpenuhi dengan 
kekuatan tekhnologi dan akses internet yang memadai. Hal ini tentu saja merupakan suatu keuntungan dari perkembangan zaman. Namun disisi lain menjadi pemicu banyaknya kemunduran dalam keutuhan ilmu yang didapat seseorang. Cermin nyata kemunduran suatu ilmu yakni kurangnya minat baca di Indonesia. Berdasarkan hasil riset Program for Internasional Student Assesment (PISA) rata-rata 493, sementara nilai literasi Indonesia hanya 396. Melihat fakta ini, tentunya Indonesia sangat jauh tertinggal. Pemerintah dan masyarakat harus mampu mengubah paradigma negatif mengenai kemampuan minat baca ini.

Ketika minat baca sesorang anak tumbuh, maka jendela dunia akan terbuka dan cara berpikir kita akan maju. Karena rendahnya minat baca anak indonesia sangat mempengaruhi kualitas bangsa Indonesia berdampak pada ketertinggalan bangsa Indonesia. Analisis Pearson atas data PISA, TIMSS (Trends in International Mathematics and Science Study), dan PIRLS (Progress in International Reading Literacy Study) menempatkan Finlandia sebagai negara dengan pendidikan terbaik pada 2016 di seluruh dunia. Studi-studi tersebut mengukur capaian akademik siswa berdasarkan penguasaan mereka di bidang matematika, sains, dan kemampuan membaca. Dari 72 negara dalam klasemen Pearson, Indonesia menempati peringkat ke 62 setingkat diatas Bostwana.

Rendahnya kemampuan membaca di Negara Indonesia, memicu pemerintah untuk memperbaiki tatanan pendidikan yang belum mengembangkan kompetensi dan minat peserta didik terhadap budaya membaca. Pemerintah sadar bahwa dengan membaca seseorang akan memperoleh berbagai pengetahuan baru yang mampu meningkatkan wawasannya sehingga mereka lebih mampu menjawab tantangan hidup kedepan yang semakin kompleks. Menurut Nurhadi (Nurhadi, 2008: 13) membaca melibatkan faktor internal dan faktor eksternal membaca.Faktor internal meliputi intelegensi (IQ), minat, sikap, bakat, motivasi, dan tujuan membaca, sedangkan faktor eksternal meliputi sarana membaca, teks bacaan, faktor lingkungan atau faktor latar belakang sosial ekonomi, kebiasaan, dan tradisi membaca.Mengingat membaca menjadi kegiatan yang mampu menstimulus seseorang menjadi pribadi yang utuh dan mampu menyerap ilmu, maka diperlukan kegiatan yang terpadu dalam pembelajaran di sekolah.

Indonesia sendiri memiliki kebudayaan yang beragam, begitu pula cerita rakyatnya. Namun, ada beberapa bagian provinsi Indonesia yang budayanya belum menjadi sorotan bahkan cenderung terisolir karena ketidaktahuan pembaca. Salah satunya adalah provinsi Bengkulu, kekurangan konten bacaan mengenai cerita rakyat bengkulu disebabkan juga karena kepunahan budaya bercerita dari turun temurun. Idealnya cerita rakyat harus tetap di berikan kepada anak, agar mampu memahami kebudayaanya dan memberikan pengajaran tentang nilai kehidupan sejalan dengan Asriyani, Rati, dan Murda (2017) cerita rakyat berfungsi sebagai media pengungkapan perilaku tentang nilai-nilai kehidupan yang melekat di dalam kehidupan masyarakat. Mengingat begitu pentingnya cerita rakyat ini, maka selayaknyalah untuk dijaga agar tidak punah seperti yang terjadi di Bengkulu.

Kepunahan akan cerita rakyat sebenarnya tidak hanya terjadi pada Bengkulu saja, ada juga beberapa daerah lain yang tidak begitu familiarnya. Hal ini terlihat dari konten bacaan pada buku siswa dan guru yang hanya menyebutkan sebagian cerita daerah lain yang selalu ada dalam buku bacaan anak seperti daerah kepulauan Jawa. Seyogyanya guru perlu memberikan sentuhan budaya lokal mengenai Bengkulu melalui cerita rakyatnya yang juga tidak kalah menarik dengan daerah lainnya. Oleh sebab itu peneliti tertarik melakukan penelitian dengan judul "Implementasi Literasi Dalam Pembelajaran Membaca Berbasis Cerita Rakyat Bengkulu Pada Siswa Kelas IV SD IT AL-QISWAH Bengkulu". Penelitian ini bertujuan untuk mengetahui implementasi literasi membaca berbasis cerita rakyat dalam mengembangkan kompetensi siswa dalam penggunaan bahasa Indonesia sesuai dengan konteks kehidupan siswa. Manfaat penelitian ini adalah sebagai 
alternatif untuk membentuk guru yang berprofesional, siswa yang memiliki kualitas akademik dan keterampilan berkomunikasi yang baik.

\section{Metode}

Jenis penelitian dalam penelitian tesis ini adalah penelitian kualitatif dengan metode deskriptif yang bertujuan untuk menganalisa implikasi gerakan literasi sekolah dalam pembelajaran membaca berbasis kearifan lokal dalam bentuk cerita rakyat yang disajikan berdasarkan tahapan gerakan literasi yakni: tahap pembiasaan, tahap pengembangan, dan tahap pembelajaran.

Menurut Maleong (2011:06) penelitian kualitatif adalah penelitian yang bermaksud untuk memahami fenomena yang dialami oleh subjek penelitian misalnya perilaku, persepsi dan lain-lain. Penelitian kualitatif dimaksudkan untuk memahami perilaku manusia dari kerangka acuan perilaku sendiri, yakni bagaimana perilaku memandang dan menafsirkan kegiatan dari segi pendiriannya.

Penelitian ini dilakukan pada tahun pelajaran 2018-2019 dimulai pada tanggal 01 Maret sampai dengan 7 Mei 2019, dan bertempat di SD IT AL-QISWAH Kota Bengkulu yang beralamat di Jalan Terminal Regional No. 01 Kelurahan Pekan Sabtu, Kecamatan Selebar Kota Bengkulu.

Intrumen penelitian terdiri dari Lembar observasi, digunakan untuk mengamati implementasi literasi dalam pembelajaran membaca berbasis cerita rakyat di SD IT AL-Qiswah Bengkulu. Lembar wawancara, lembar wawancara yang berisi pertanyaan-pertanyaan yang harus dijawab oleh sumber data secara lisan untuk mendapatkan data yang sesuai dengan tujuan penelitian, dan dokumentasi, digunakan untuk mengumpulkan data yang dilakukan dengan cara menghimpun atau mengumpulkan dokumen-dokumen yang berisi catatan peristiwa yang sudah berlalu, bisa berbentuk tulisan, gambar, atau karya-karya dari seseorang.

Teknik pengumpulan data dalam penelitian ini adalah observasi, wawancara, dan dokumentasi.

Analisis data dalam penelitian ini mengarah pada analisis deskriptif atau analisis yang menggambarkan informasi faktual.

Pengecekan keabsahan temuan dalam penelitian ini, untuk mengukur validitas dan memperkuat kredibilitas dengan menggunakan trianggulasi dan member check.

\section{Hasil}

Hasil penelitian ini meliputi (1) implementasi literasi dalam pembelajaran membaca berbasis cerita rakyat Bengkulu pada tahap pembiasaan (2) implementasi literasi dalam pembelajaran membaca berbasis cerita rakyat Bengkulu pada tahap pengembangan (3) implementasi literasi dalam pembelajaran membaca berbasis cerita rakyat Bengkulu pada tahap pembelajaran.

1. Implementasi Literasi Dalam Pembelajaran Membaca Berbasis Cerita Rakyat Bengkulu Pada Tahap Pembiasaan di Kelas IV SD IT AL-Qiswah Bengkulu

Implementasi gerakan literasi yang ada di SD IT AL-Qiswah Bengkulu yaitu mengacu penuh pada buku pedoman yang diterbitkan oleh kementerian pendidikan dan kebudayaan (kemendikbud). Buku yang berjudul gerakan literasi sekolah yang ada di sekolah tersebut didapat melalui fasilitas internet dengan cara mendownload sendiri, sebab kemendikbud tidak mendistribusikan buku panduan literasi yang diterbitkanya secara langsung kesekolah-sekolah. Adapun buku tersebut berisi mengenai tahapan-tahapan gerakan literasi yang secara keseluruhan dibagi menjadi 
tiga tahapan, yaitu pertama tahap pembiasaan, kedua tahap pengembangan dan yang ketiga tahap pembelajaran.

Berikut adalah proses impelentasi gerakan literasi pada tahap pembiasaan yang ada di sekolah SD IT AL-Qiswah Bengkulu yaitu :

a.Kegiatan membaca lima belas menit buku non pelajaran.

Hasil Observasi pada saat kegiatan membaca 15 menit buku non pelajaran di waktu sebelum pembelajaran di mulai menunjukkan bahwa, peserta didik di kelas IV SD IT AL-Qiswah Bengkulu tampak sudah terbiasa dengan kegiatan literasi yang dilakukan. Dokumentasi menunjukkan kegiatan 15 menit buku non pelajaran dilakukan di awal pembelajaran. Hal ini terlihat di langkah RPP Tema 8 Subtema 1 lingkungan tempat tinggalku.

Hasil wawancara, ada beberapa hal yang perlu dipersiapkan sebelum pembelajaran membaca, hal ini dikatakan oleh guru bahwa gerakan literasi dimulai pada pukul 07:00 WIB, lima belas menit sampai dengan pukul 07:15 WIB setelah bel tanda masuk berbunyi anak memasuki ruang kelas, apabila sudah terdengar pengumuman atau informasi melalui sepaker di tiap-tiap kelas untuk memulai gerakan literasi maka siswa mengambil atau mempersiapkan buku yang telah dibawanya untuk dibaca. Tidak ada batasan jumlah halaman yang harus di capai oleh anak dalam proses gerakan literasi ini yang terpenting anak mau membaca saja. Setelah selesai membaca maka buku disimpan kembali atau diletakan di pojok perpustakaan kelas yang telah tersedia lalu kemudian untuk bisa di rolling gantian ditukar acak dengan teman satu kelas untuk dibaca pada saat gerakan literasi di mulai. Kemudian baru dilanjutkan pelajaran seperti biasa. Kegiatan membaca 15 menit buku non pelajaran berjalan tercapai pada saat pelaksanaan.

b.Pencatatan identitas buku bacaan

Hasil Observasi mengenai proses pencatatan identitas buku bacaan dilakukan berdasarkan keinginan peserta didik dalam mempersiapkan kegiatan respon baca ketika guru meminta mereka bercerita mengenai buku bacaan cerita rakyat Bengkulu dan ini juga menggali potensi siswa dalam memahami cerita yang dibaca oleh peserta didik. Pencatatan identitas buku bacaan terlihat dari adanya jurnal membaca harian peserta didik yang dapat berupa bentuk buku, kartu, atau selembar kertas didalam portofolio. Guru kelas IV SD IT AL-Qiswah Bengkulu meminta peserta didik untuk menyiapkan jurnal baca. Selain itu pengelola perpustakaan juga melakukan tugasnya dalam mengelola perpustakaan. Kegiatan pencatatan identitas buku bacaan tercapai, dilihat dari siklus peminjaman buku di perpustakaan SD IT AL-Qiswah Bengkulu dan pencatatan identitas buku bacaan siswa.

c.Kegiatan kontrol guru tentang bacaan siswa

Hasil observasi menunjukkan, kegiatan bertanya tentang isi buku dilakukan oleh guru kelas IV SD IT AL-Qiswah Bengkulu. Kegiatan ini berbarengan dengan kegiatan setelah membaca 15 menit buku non pelajaran buku cerita rakyat Bengkulu. Guru juga meminta anak untuk memberikan jurnal bacaan, jurnal bacaan ini berisi tentang perkembangan anak dalam membaca buku bacaan yakni melihat perkembangan nilai ketutasan membaca siswa setiap 2 minggu sekali. Hal ini sangat membantu guru dalam bertanya mengenai buku apa saja dan apa yang peserta didik dapatkan dari cerita yang dibaca. Kegiatan kontrol bacaan siswa dapat membantu guru menilai perkembangan siswa.

d.Perpustakaan yang lengkap, tersusun rapi dan memiliki rak khusus untuk buku non pelajaran

Perpustakaan sebagai pusat pembelajaran di SD IT AL-Qiswah Bengkulu. Pengembangan dan penataan perpustakaan menjadi bagian dari pelaksanaan gerakan literasi dan pegelolaan pengetahuan yang berbasis pada bacaan, terlihat 
adanya rak khusus buku non fiksi yakni buku cerita rakyat Bengkulu, dongeng anak, cerita Nabi dan tatanan yang rapi dalam penyusunan buku. Perpustakaan menjadi pilihan yang nyaman dalam membaca buku dan mencari sumber data yang dibutuhkan. Perpustakaan mampu menjadi perantara sekolah dalam mengembangkan literasi membaca terlihat dari munculnya catatan mengenai siklus buku di perpustakaan hasil dokumentasi menunjukkan SD IT Al-Qiswah menunjukkan perpustakaan yang lengkap dan tersusun rapi.

e.Memiliki sudut baca dan poster membaca.

Sudut baca kelas adalah sebuah sudut yang dilengkapi dengan koleksi buku yang ditata secara menarik untuk menumbuhkan minat baca peserta didik.Sudut baca kelas adalah sudut yang digunakan untuk memajang koleksi bacaan dan karya peserta didik. Sudut baca menjadi penunjang dalam proses literasi membaca dan menjadi solusi yang tepat agar siswa memiliki motivasi membaca.Sudut baca juga menjadi tempat yang nyaman untuk diskusi membaca siswa diwaktu istirahat sekolah dokumentasi menunjukkan adanya sudut baca pada kelas IV SD IT AlQiswah.

f.Bersama tim literasi dan alumni melakukan kegiatan literasi

Pengembangan sarana literasi membutuhkan sumber daya yang memadai. Partisipasi komite sekolah, orang tua, alumni dapat membantu memelihara dan mengembangkan sarana sekolah agar capaian literasi peserta didik dapat terus ditingkatkan. Sekolah dan tim literasi telah berkoordinasi agar terciptanya lingkungan literasi yang baik di SD IT AL-Qiswah Bengkulu. Tim literasi terdiri dari guru dan pengelola perpustakaan terlihat dari munculnya pencatatan identitas buku pada perpustakaan dan guru kelas IV.

\section{Implementasi Literasi Dalam Pembelajaran Membaca Berbasis Cerita Rakyat Bengkulu Pada Tahap Pengembangan di Kelas IV SD IT AL-Qiswah Bengkulu.}

Proses tahapan pengembangan ini, guru menggunakan peta cerita sebagai kegiatan lanjutan. Semua peserta didik didorong untuk menuliskan ringkasan cerita/buku dan respon mereka didalam peta cerita.Prinsip kegiatan adalah tanpa penilaian akademik.Untuk mendorong dan memberikan apresiasi peserta didik atas upaya mereka, peta cerita/ buku yang sudah diisi mendapatkan reward bintang karakter. Adapun tahapan pengembangan dilakukan dengan cara berikut ini:

a.Kegiatan membaca lima belas buku non pelajaran setiap hari diawal, ditengah dan diakhir pembelajaran yang dilakukan seluruh warga sekolah. Hasil Observasi menunjukkan bahwa seluruh warga SD IT AL-Qiswah Bengkulu memerlukan buku dalam menunjang kegiatan mereka. Guru membaca buku cerita rakyat Bengkulu untuk membantu kelancaran prsoses belajar mengajar, peserta didik mencari hiburan dengan mengunjungi sudut baca atau perpustakaan di SD IT AL-Qiswah Bengkulu. Peserta didik dan seluruh warga sekolah SD IT AL-Qiswah Bengkulu bersama-sama mempersiapkan dan mengkondisikan kelas untuk memulai kegiatan literasi dalam tahap pengembangan dengan baik hasil dokumentasi menunjukkan adanya kegiatan membaca 15 menit buku non pelajaran terdapat di RPP Tematik

b.Kegiatan respon bacaan baik secara lisan maupun tulisan. Hasil Observasi menunjukkan kegiatan respon baca di SD IT AL-Qiswah berjalan dengan baik.Kegiatan ini biasanya dilakukan setelah membaca15 menit buku non pelajaran.Guru akan meminta peserta didik mengajukan pertanyaan dan guru kembali mengajukan pertanyaan seandainya peserta didik tidak bertanya. Kegiatan sesi tanya jawab mampu menunjang kegiatan siswa untuk memahami isi bacaan 
hasil dokumentasi menunjukkan adanya kegiatan membaca 15 menit buku non pelajaran terdapat di RPP Tematik 8.1

c.Tagihan lisan dan tulisan penilaian non akademik. Hasil observasi menunjukkan bahwa kegiatan tagihan lisan dan tulisan akan selalu dilakukan meski tidak dilakukan penilaian akademik. Kegiatan ini adalah kegiatan lanjutan setelah sesi Tanya jawab mengenai hasil bacaan peserta didik. Tagihan lisan ini hanya terjadi di sesi tanya jawab namun, peserta didik juga diminta untuk menyerahkan catatan jurnal harian. Catatan jurnal harian peserta didik berisi tentang perkembangan buku bacaan yang mereka baca. Guru dan siswa memiliki motivasi yang tinggi, sehingga literasi membaca menjadi lebih menyenangkan.

d.Memiliki portofolio kumpulan jurnal respon baca. Hasil observasi menunjukkan bahwa kegiatan dalam mengumpulkan portofolio peserta didik di kelas IV SD IT ALQiswah Bengkulu yakni dengan mengumpulkan hasil jurnal baca peserta didik. Guru melakukan literasi terlihat dari kumpulan portofolio peserta didik, bahwa untuk mengetahui perkembangan bacaan siswa diperlukan adanya pencatatan buku yang bisa berupa jurnal bacaan siswa hasil dokumentasi menunjukkan adanya portofolio.

e.Memiliki jurnal respon membaca. Jurnal respon baca adalah instrument berupa table rekaman capaian membaca peserta didik yang dilakukan 15 menit setiap hari. Bentuk dapat berupa buku, kartu, atau selembar kertas didalam portofolio kegiatan membaca. Guru memantau perkembangan membaca peserta didik melalui jurnal baca. Peserta didikpun memiliki kegiatan setelah mereka membaca buku agar karakter cerita bisa lebih dipahami oleh peserta didik hasil dokumentasi menunjukkan guru memiliki jurnal respon baca peserta didik.

f.Ada penghargaan capaian literasi. Penghargaan capaian literasi, menjadi motivasi peserta didik agar proses literasi menjadi menyenangkan. Peserta didik akan lebih terpacu dalam menyelesaikan tugas dari guru khususnya dalam membaca. Penghargaan capaian literasi peserta didik di kelas IV SD IT AL-Qiswah Bengkulu berupa bintang karakter. Guru dan peserta didik melakukan proses literasi dengan memberikan motivasi untuk peserta didik, sehingga kegiatan ini akan terasa lebih bermakna.

\section{Implementasi Literasi Dalam Pembelajaran Membaca Berbasis Cerita Rakyat Bengkulu Pada Tahap Pembelajaran di Kelas IV SD IT AL-Qiswah Bengkulu}

Kegiatan literasi pada tahapan pembelajaran yakni meningkatkan kemampuan berbahasa reseptif (membaca dan menyimak) dan aktif (berbicara dan menulis) yang dijelaskan secara rinci dalam konteks dua bagian utama di tahap ini, yaitu membaca dan menulis. Adapun tahapan literasi pembelajaran yaitu:

a.Kegiatan membaca membudaya dan menjadi kebutuhan. Hasil observasi menunjukkan seluruh warga sekolah SD IT AL-Qiswah Bengkulu melakukan poses Literasi sebagai rutinitas harian sekolah, peserta didik dan guru mencari sumber data dan hiburan melalui sarana dan fasilitas sekolah yakni, Perpustakaan dan sudut baca kelas, hal ini terlihat di waktu istirahat sekolah. Peserta didik setiap harinya akan tampak terlihat berada di perpustakaan dan juga sudut baca kelas. Literasi menjadi budaya sekolah SD IT AL-Qiswah Bengkulu. Guru, dan perpustakaan memiliki peran penting dalam memberikan motivasi warga sekolah dalam membaca terlihat pada siklus baca di perpustakaan dan kegiatan guru dalam membaca diluar jam pembelajaran sekolah.

b.Melaksanakan strategi untuk memahami teks bacaan. Hasil observasi menunjukkan bahwa guru kelas IV SD IT AL-Qiswah Bengkulu memerlukan 
beberapa strategi agar proses literasi membaca berjalan dengan lancar dan baik. Strategi guru SD IT AL-Qiswah Bengkulu melaksanakan proses literasi dengan sesi jawab dan menceritakan karakter tokoh dalam cerita.

c.Peserta didik menggunakan lingkungan fisik, afektis, social, dan akademik beragam bacaan. Hasil Observasi menunjukkan lingkungan fisik SD IT AL-Qiswah Bengkulu berupa karya peserta didik dipajang sepanjang lingkungan, buku dan materi bacaan lain tersedia di sudut baca semua ruang kelas, Kepala sekolah bersedia berdialog dengan warga sekolah dan lingkungan sekitar sekolah.

d.Ada unjuk karya kemampuan literasi. Hasil observasi di SD IT AL-Qiswah Bengkulu menunjukkan bahwa setiap kelas memiliki cara yang beragam dalam memberikan warna dan mempercantik ruangan kelas. Guru juga menunjukkan karya peserta didik dengan dipajang di dinding kelas. Beberapa karya tampak menghias dinding kelas. Begitu banyak warna dan tema yang diberikan oleh peserta didik. Sehingga, ruangan kelas di SD IT AL-Qiswah Bengkulu tampak begitu semarak. Karya peserta didik di SD IT AL-Qiswah Bengkulu terlihat terpampang di dinding seluruh kelas bisa berbentuk madding dan juga kantong karya siswa.

e.Sekolah berjaring dengan pihak eksternal untuk pengembangan literasi sekolah. Pengembangan sarana literasi membutuhkan sumber daya yang memadai. Hasil observasi menunjukkan adanya partisipasi komite sekolah, orang tua, alumni dapat membantu memelihara dan mengembangkan sarana sekolah agar capaian literasi peserta didik dapat terus ditingkatkan.

\section{Pembahasan}

Pembahasan dipaparkan berdasarkan hasil temuan penelitian yaitu (1) implementasi literasi dalam pembelajaran membaca berbasis cerita rakyat Bengkulu pada tahap pembiasaan (2) implementasi literasi dalam pembelajaran membaca berbasis cerita rakyat Bengkulu pada tahap pengembangan (3) implementasi literasi dalam pembelajaran .membaca berbasis cerita rakyat Bengkulu pada tahap pembelajaran.

1. Implementasi Literasi Dalam Pembelajaran Membaca Berbasis Cerita Rakyat Bengkulu Pada Tahap Pembiasaan di Kelas IV SD IT AL-Qiswah Bengkulu

Implementasi literasi membaca pada tahapan pembiasaan di SD IT AL-Qiswah berjalan dengan baik dan terarah. Terbukti munculnya semua indikator pada tahapan pembiasaan.

Tahapan Pembiasaan yakni penumbuhan minat baca melalui kegiatan 15 menit membaca (Permendikbud No. 23 Tahun 2015). Tahapan pembiasaan memiliki beberapa indikator diantaranya :

a.Kegiatan membaca lima belas menit buku non pelajaran setiap hari sebelum pembelajaran yang dilakukan seluruh warga sekolah.

Kegiatan siswa kelas IV SD IT AL-Qiswah Bengkulu yakni guru menyiapkan kondisi dan waktu untuk peserta didik ketika membaca buku non pelajaran dan peserta didik membaca buku pilihan sesuai dengan minat peserta didik. Menurut permendikbud No. 23 Tahun 2015 tentang menumbuhkan motivasi minat membaca melalui kegiatan membaca 15 menit buku non pelajaran. Kegiatan ini mampu menunjang daya imajinasi anak dan peningkatan minat baca peserta didik.

b.Pencatatan identitas buku bacaan, kegiatan bertanya tentang isi buku dilakukan 2-3 minggu sekali. 
Perpustakaan menjadi wadah untuk warga SD IT AL-Qiswah Bengkulu dalam mencari sumber data. Perpustakaan yang baik dikelola oleh pengelola perpustakaan dalam mengatur jalannya perpustakaan SD IT AL-Qiswah Bengkulu. Tugas pengelola perpustakaan melihat perkembangan minat baca warga SD IT AL-Qiswah Bengkulu dilihat dari daftar kunjungan perpustakaan dan juga catatan peminjaman buku di perpustakaan. Selain itu, guru juga akan mencatat perkembangan bacaan siswa dilihat dari jurnal baca siswa.

c.Perpustakaan yang lengkap, tersusun rapi dan memiliki rak khusus untuk buku non pelajaran.

Kondisi perpustakaan SD IT AL-Qiswah Bengkulu, meski tidak terlalu luas namun tertata dengan rapi dan memiliki rak khusus buku non pelajaran. Perpustakaan SD IT AL-Qiswah menjadi tempat yang nyaman untuk membaca dan mencari buku bacaan. Menurut Ibrahim (2009) perpustakaan sekolah tampak bermanfaat apabila benar-benar memperlancar pencapaian tujuan proses belajar-mengajar di sekolah, indikasi manfaat tersebut tidak hanya berupa tingginya prestasi murid-murid tetapi lebih jauh lagi adalah murid-murid mampu mencari, menemukan, menyaring, dan menilai informasi, murid-murid terbiasa belajar mandiri, terlatih kearah tanggung jawab, selalu mengikuti perkembangan ilmu pengetahuan dan teknologi. Perpustakaan ini setiap harinya selalu memiliki pengunjung baik guru, peserta didik maupun staf sekolah.

d.Memiliki sudut baca dan poster membaca.

Sudut baca di kelas IV SD IT AL-Qiswah Bengkulu terlihat cantik dan rapi. Guru dan peserta didik menata sudut baca dengan kerajinan tangan peserta didik. Kerajinan tangan dapat berupa lukisan, gambar, potongan gambar dan poster membaca. Sudut bacapun memiliki buku yang beragam yakni buku dongeng, cerita rakyat, ensiklopedia dan cerita nabi. Sudut baca yang nyaman mampu menarik minat baca peserta didik di kelas IV SD IT AL-Qiswah Bengkulu. Sudut baca merupakan sebuah tempat yang terletak di sudut ruangan yang dilengkapi dengan koleksi buku. Kemendikbud (2016:17) menjelaskan bahwa sudut baca merupakan sebuah ruangan yang terletak di sudut kelas yang dilengkapi dengan koleksi buku dan berperan sebagai perpanjangan fungsi perpustakaan. Melalui sudut baca siswa dilatih untuk membiasakan membaca buku, sehingga menjadikan siswa gemar membaca.

e.Bersama tim literasi dan alumni melakukan kegiatan literasi.

Kepala sekolah SD IT AL-Qiswah Bengkulu, telah membuat tim literasi yang beranggotakan seluruh dewan guru, pengelola perpustakaan dan tentunya wali murid SD IT AL-Qiswah Bengkulu. Pembentukan tim diperlukan untuk pengadaan buku di SD IT AL-Qiswah Bengkulu. Guru dan wali peserta didik bersedia menyumbangkan buku dan membantu proses kegiatan literasi di sekolah agar berjalan dengan lancar.

Kegiatan literasi selama ini identik dengan aktivitas membaca dan menulis. Namun, Deklarasi Praha pada tahun 2003 menyebutkan bahwa literasi juga mencakup bagaimana seseorang berkomunikasi dalam masyarakat. Literasi juga bermakna praktik dan hubungan sosial yang terkait dengan pengetahuan, bahasa, dan budaya (UNESCO, 2003).

\section{Implementasi Literasi Dalam Pembelajaran Membaca Berbasis Cerita Rakyat Bengkulu Pada Tahap Pengembangan di Kelas IV SD IT AL-Qiswah Bengkulu}

Tahap pengembangan minat baca untuk meningkatkan kemampuan literasi. Kegiatan literasi pada tahap ini bertujuan mengembangkan kemampuan memahami 
bacaan dan mengaitkannya dengan pengalaman pribadi, berpikir kritis, dan mengolah kemampuan komunikasi secara kreatif melalui kegiatan menanggapi bacaan pengayaan (Anderson \& Krathwol, 2001).

Tahap pengembangan ini mampu Meningkatkan kemampuan literasi peserta didik di kelas IV SD IT AL-Qiswah Bengkulu yakni melalui kegiatan menanggapi buku pengayaan. Kegiatan Literasi di Tahap Pengembangan, diantaranya yaitu:

a.Kegiatan membaca lima belas menit buku non pelajaran setiap hari diawal, ditengah dan diakhir pembelajaran yang dilakukan seluruh warga sekolah.

Kegiatan membaca lima belas menit buku non pelajaran selalu diawali dengan perasaan senang karena guru membudayakan kegiatan membaca. Kegiatan ini diawali dengan berdoa dan memilih buku baca. Kegiatan ini lebih menekankan bagaimana anak sudah mulai terbiasa dengan kegiatan membaca dan merasa bahwa kegiatan ini menjadi rutinitas setiap harinya. Kegiatan membaca buku non pelajaran terlihat didalam rangkaian kegiatan RPP tema 8. Guru kembali mengaitkan cerita dengan tema lingkungan.

Guru menceritakan mengenai cerita rakyat yang berasal dari Bengkulu. Cerita mengenai Puteri Gading Cempaka merupakan puteri berasal dari daerah Bengkulu yang tentunya peserta didik perlu mengenal cerita ini. Buku non pelajaran yang digunakan kelas IV SD IT AL-Qiswah Bengkulu yakni berupa buku fiksi. Menurut Nurgiantoro (2010) Fiksi adalah prosa naratif yang memiliki sifat imajinatif.

b.Kegiatan respon bacaan baik secara lisan maupun tulisan.

Kegiatan ini dilakukan setelah peserta didik dan guru membaca cerita yang menarik untuk didiskusikan. Pentingnya respon membuat guru kelas IV SD IT AL-Qiswah Bengkulu, melakukan kegiatan ini agar siswa mampu melatih diri untuk memahami cerita dan tentunya berbicara. Menurut (Kartono, 2014:431) respon adalah suatu jawaban, khususnya satu jawaban bagi pertanyaanatau satu kuesioner atau seberang tingkah laku, baik yang jelas kelihatan atau lahirilah maupun 33 yang tersembunyi atau tersamar.

Rangsangan yang baik mengenai pemahaman cerita, mampu melatih peserta didik khususnya kelas IV SD IT AL-Qiswah Bengkulu menjadi lebih kreatif, imajinatif dan mampu dalam melatih kemampuan berbicara peserta didik.

c.Tagihan lisan dan tulisan penilaian non akademik.

Tagihan lisan dan tulisan peserta didik kelas IV dilihat dari catatan jurnal dan repon baca yang dilakukan peserta didik. Namun, tidak ada skor nilai untuk hasil bacaan ini. Jurnal baca siswa ini membantu guru melihat perkembangan bacaan peserta didik. Tagihan lisan dan tulisan ini juga mampu menunjukkan perkembangan dari kemampuan membaca peserta didik. Menurut Sadhono dan Slamet dalam Purnamasari (2014:12) keterampilan membaca adalah keterampilan mengenal dan memahami tulisan dalam bentuk urutan lambang-lambang grafis dan perubahannya menjadi wicara bermakna dalam bentuk pemahaman diam-diam atau pengujaran keras-keras. Kegiatan membaca dapat bersuara dan dapat pula tidak bersuara.

d.Memiliki portofolio kumpulan jurnal respon baca.

Portofolio peserta didik kelas IV SD IT AL-Qiswah Bengkulu merupakan kumpulan dari jurnal respon baca siswa, nilai membaca dan juga beberapa karya dari hasil membaca. Peserta didik memiliki jurnal respon baca yang menunjukkan perkembangan bacaan mereka. Karya peserta didik berupa kerajinan tangan, gambar, dan juga beberapa tulisan peserta didik.

Secara etimologi, portofolio berasal dari dua kata, yaitu port (singkatan dari report) yang berarti laporan dan folio yang berarti penuh atau lengkap. Menurut 
Surapranata dan Hatta (2004), portofolio diartikan sebagai kumpulan karya atau dokumen siswa yang tersusun secara sistematis dan terorganisasi yang diambil selama proses pembelajaran, digunakan oleh guru dan siswa untuk menilai dan memantau perkembangan pengetahuan, keterampilan, dan sikap siswa dalam mata pelajaran tertentu.

e.Memiliki jurnal respon membaca.

Guru SD IT AL-Qiswah Bengkulu dalam kegiatan pembelajaran selalu meminta peserta didik untuk menunjukkan jurnal baca. Jurnal baca ini dimaksudkan untuk melihat perkembangan bacaan siswa. Isi jurnal baca ini berupa judul, pengarang, halaman, dan waktu membaca siswa. Membaca jurnal baca siswa mampu memprediksi minat baca siswa, meski tidak bertemu di kelas. Menurut Sandjaya (2005) bahwa minat membaca adalah sikap positif dan adanya rasa keterikatan dalam diri anak terhadap aktivitas membaca dan tertarik terhadap buku bacaan. Aspek minat membaca meeliputi kesenangan membaca, frekuensi membaca, dan kesadaran akan menfaat membaca. Berdasarkan pendapat tersebut menunjukkan bahwa jurnal baca mampu memprediksi minat baca seseorang.

f.Ada penghargaan capaian literasi.

Penghargaan capaian literasi pada siswa kelas IV peserta didik berupa bintang karakater. Bintang karakter ini berupa bentuk bintang yang bertuliskan kata motivasi siswa, yakni disiplin, kreatif, sosial, dan rajin. Reward pada peserta didik sangat diperlukan, yakni memotivasi peserta didik memperoleh kepercayaan dirinya dalam setiap pembelajaran. Sehingga potensi yang ada pada peserta didik mampu berkembang dengan baik.

3. Implementasi Literasi Dalam Pembelajaran Membaca Berbasis Cerita Rakyat Bengkulu Pada Tahap Pembelajaran di Kelas IV SD IT AL-Qiswah Bengkulu

Pelaksanaan pembelajaran berbasis literasi Kegiatan literasi pada tahap pembelajaran bertujuan mengembangkan kemampuan memahami teks dan mengaitkannya dengan pengalaman pribadi, berpikir kritis, dan mengolah kemampuan komunikasi secara kreatif melalui kegiatan menanggapi teks buku bacaan pengayaan dan buku pelajaran (Anderson \& Krathwol, 2001). Dalam tahap ini ada tagihan yang sifatnya akademis (terkait dengan mata pelajaran).

Tahap pembelajaran yakni meningkatkan kemampuan literasi di semua mata pelajaran dengan menggunakan buku pengayaan dan strategi membaca di semua mata pelajaran.

Kegiatan membaca pada tahap ini untuk mendukung pelaksanaan Kurikulum 2013 yang mensyaratkan peserta didik membaca buku nonteks pelajaran yang dapat berupa buku tentang pengetahuan umum, cerita rakyat Bengkulu, kegemaran, minat khusus, atau teks multimodal, dan juga dapat dikaitkan dengan mata pelajaran tertentu sesuai tema bagi siswa SD, Buku laporan kegiatan membaca pada tahap pembelajaran ini disediakan oleh wali kelas.

Teori diatas tersebut sesuai dengan produk atau hasil kegiatan literasi sekolah yang ada di SD IT AL-Qiswah Bengkulu, sebagai identifikasi menuju tahap pembelajaran yaitu sudah menjadikan anak mampu berfikir kritis menanggapi buku dan menulisnya dari apa yang mereka baca serta mampu menceritakanya di depan kelas, mengekspresikan ide mereka berbentuk poster dengan tema yang berkaitan dengan gerakan literasi, lebih lanjutnya yaitu ada tagihan kegiatan berbasis buku pelajaran.

Guru juga akan memberikan pertanyaan uraian dalam teks cerita rakyat Bengkulu. Terlihat dari soal pertanyaan berdasarkan kisah Puteri Gading Cempaka, Batu menangis dan Telaga dewa dalam seminggu pertemuan observasi yang dilakukan peneliti. 
Kegiatan pada tahap pembelajaran peserta didik yang dilakukan guru yakni pembelajaran tematik tidak begitu berjalan dengan lancar. Hal ini perlu bimbingan khusus bagi peserta didik yang belum lancar dalam membaca. Peserta didik juga perlu bimbingan untuk menanggapi dan memahami bacaan. Peserta didik memiliki perbedaan kemampuan dalam memahami bacaan, Ketika pembelajaran berlangsung peserta didik tidak semua memiliki minat dalam membaca buku. Rendahnya minatpun memiliki alasan yang beragam yakni: merasa jenuh, bosan dan tidak suka membaca. Guru harus mampu membimbing peserta didiknya agar senang dan merasa tak terbebani ketika membaca. Sehingga diharapkan terbentuklah peserta didik yang literat namun mencintai budayanya.

Pengadaan cerita rakyat Bengkulu juga memiliki kendala, yakni kurangnya buku mengenai cerita rakyat Bengkulu dan referensi cerita yang tidak banyak jumlahnya.

\section{Kesimpulan}

Berdasarkan hasil kajian dan pemahaman yang mengacu pada rumusan masalah yang telah ditetapkan serta berdasarkan analisis data yang diuraikan secara deskriptif pada bab IV, maka dapat disimpulkan bahwa:

1. Implementasi literasi pada tahapan pembiasaan yakni menumbuhkan minat baca melalui 15 menit membaca buku non pelajaran yang dibimbing oleh guru kelas, kegiatan literasi yang ada di sekolah dapat berjalan dengan nyaman jika guru memperbanyak referensi buku cerita rakyat terutama cerita rakyat Bengkulu.

2. Implementasi literasi pada tahap pengembangan yaitu siswa menganalisis atau menceritakan kembali buku yang telah mereka baca. Guru memberikan simulasi tentang isi bacaan dalam menggali pengalaman bacaan peserta didik sesuai dengan karakter tokoh cerita rakyat Bengkulu.

3. Implementasi literasi pada tahap pembelajaran yaitu dilakukan oleh guru sejak awal dalam perancangan RPP yang diintegrasikan dengan buku bacaan dan tematik dalam menyiapkan tagihan akademik peserta didik.

\section{Saran}

Berdasarkan kesimpulan dari penelitian, maka penulis pada bagian ini mengemukakan saran kepada:

1. Implementasi literasi pada pembelajaran membaca berbasis cerita rakyat Bengkulu pada tahap pembiasaan guru meminta orang tua peserta didik turut menerapkan kegiatan literasi membaca di rumah agar peserta didik sudah terbiasa membaca dan membaca menjadi kebutuhan.

2. Implementasi literasi pada pembelajaran membaca berbasis cerita rakyat Bengkulu pada tahap pengembangan, hendaknya guru mengalokasikan waktu kegiatan 15 menit membaca buku non pelajaran ditambah dengan kegiatan menulis menanggapi buku dan membuat karya hasilbacaan peserta didik baik berupa karangan atau puisi, agar peserta didik lebih memahami buku bacaan.

3. Implementasi literasi pada pembelajaran membaca berbasis cerita rakyat Bengkulu pada tahap pembelajaran, hendaknya sekolah SD IT AL-Qiswah Bengkulu memiliki perlombaan antar kelas bertemakan literasi membaca dan memberikan penghargaan untuk peserta didik yang berprestasi. 


\section{Referensi}

Asriyani, Rati, dan Murda. (2017). Pemanfaatan Buku Cerita Bergambar Sebagai Sumber Bacaan Siswa SD. Jurnal Pendidikan. Volume: 1 Nomor: 5 Halaman: 989-992.

Anderson, L dan Krathwohl, D, 2011, Kerangka Landasan Untuk Pembelajaran, Pengajaran, Pengajaran dan Asesmen Revisi Taksonomi Pendidikan Bloom. Yogyakarta: Pustaka Pelajar

Axford. 2009. Scaffolding Literacy: An integrated and sequential approach to teaching, reading, spelling and writing. Australia, ACER Press.

Brumfit, Christopher, and R. A. Carter. English Literature and English Language. , Literature and Language Teaching. Oxford: Oxford University Press, 1987. 2-21.

Brown, H. Douglass. 2001. Teaching by Principles: An Interactive Aproach to Language Pedadogy. San Fransisco: State University.

Dewi Utama Faizah, dkk. 2016. Panduan Gerakan Literasi Sekolah Di Sekolah Dasar. (Jakarta) : Direktorat Jenderal Pendidikan Dasar dan Menengah Kementrian Pendidikan dan Kebudayaan.

Djamarah, Syaiful Bahri. (2008). Psikologi Belajar. Jakarta: Rineka Cipta

Ibrahim Baladal. 2009. Pengelolaan Perpustakaan Sekolah. Bandung: Bumi Aksara

Kartono, Kartini, 2014, Patologi Sosial 2 : Kenakalan Remaja, Jakarta : Rajawali Press

Kemendikbud. (2016). Permendikbud Nomor 22 Tahun 2016 Tentang Standar Proses Pendidikan Dan Menengah. Jakarta: Kemendikbud

Kern, Richard. 2000. Literacy and Language Teaching. Oxford: Oxford University Press.

Miles dan Huberman. 1992. Analisis data Kualitatif. (diterjemahkan Ole: Tjetjep Rohedi Rosidi). Jakarta: Universitas Indonesia.

Moleong, LJ. 2007. Metodologi Penelitian Kualitatif. Bandung: Remaja Rosdakarya.

Nurgiyantoro, Burhan. 2010. Sastra Anak: Pengantar Pemahaman Dunia Anak. Yogyakarta: Gajah Mada University Press.

Padmanugraha. 2010. Common Sense Outlook on Local Wisdom and Identity: A Contemporary Javanese Native's Experience. Presented in International Conference on Local Wisdom for Character Building on May 29, 2010

Peraturan Menteri Pendidikan dan Kebudayaan Nomor 23 Tahun 2015. Pengembangan Gerakan Literasi. Jakarta: Kemendikbud.

Sanjaya, Wina (2005). Pembelajaran dan Implementasi Kurikulum Berbasis Kompetensi, Jakarta: Kencana

Supartinah. 2007. Pemetaan Nilai Pendidikan Budaya dan Karakter Mata pelajaran Bahasa Jawa Kelas Rendah SD di DIY. Hasil Penelitian Dosen Junior, tidak diterbitkan. Universitas Negeri Yogyakarta.

Surapranata dan Muhammad Hatta. 2004. Penilaian Portofolio. Bandung: PT Remaja Rodakarya.

Undang-Undang RI No. 20 Tahun 2003. Sistem Pendidikan Nasional. Jakarta: Lembaga Informasi Nasional.

UNESCO. 2000. The Dakar Framework for Action. Paris: UNESCO.

UNESCO. 2W3a. Literacy as Freedom: a UNESCO Roundtable. Pads: UNESCO.

Vincent, David. 2000. The rise of mass literacy: reading and writing in modem Europe. London: Polity Press.

Winarni, Endang, Widi. 2011. Penelitian Pendidikan. Bengkulu: FKIP Universitas Bengkulu 
Winarni, Endang, Widi. 2018. Teori dan Praktik Penelitian Kuantitatif, Kualitatif, PTK, R\&D. Jakarta: Bumi Aksara

Wikipedia. 2019. Literasi. https://id. wikipedia. org/wikiLiterasil. Diunduh pada tanggal 2 Februari 2019

https://www. senibudayaku. com/2017/05/kebudayaan-provinsi-bengkulu. html. (diunduh pada tanggal 4 januari 2019.

https://bagawanabiyasa. wordpress. com/2018/01/21/pendidikan-berbasis-kearifan-lokal/

https://filediamant. wordpress. com/2012/03/18/65-model-pembelajaran-dan-15-metode-pem www. literasimedia. org/literasi-media/ www. prioritaspendidikan. org. pelajaran/

A. S. Padmanugraha, 'Common Sense Outlook on Local Wisdom and Identity: A Contemporary Javanese Natives' Experience' Paper Presented in International Conference on Local Wisdom for Character Building, (Yogyakarta: 2010) https://id. wikipedia. org/wiki/Kearifan_lokal, diakses tanggal 12 Februari 2019.

Abdul Muktadir, Model Bahan Ajar Mulok Berbasis Cerita Rakyat Untuk Pendidikan Karakter DI SD. (Bengkulu: 2018) https://www. literasipublik. com/literasi-baca-tulis), diakses pada tanggal 1 Februari 2019.

Aceng Joyo, Gerakan Literasi Dalam Pembelajaran Bahasa Indonesia Berbasis Kearifan Lokal Menuju Siswa Berkarakter. (Bengkulu: 2018) https://media. neliti. com/media/publications/256081-gerakan-literasi-dalam-pembelajaran-baha-dc455f80. pdf, diakses tanggal 12 Februari 2019.

Henry Subandiyah, Pembelajaran Literasi Dalam Mata Pelajaran Bahasa Indonesia. (Surabaya2016 )file:///C:/Users/hp/Downloads/27-27-1-PB. pdf

Diakses tanggal 13 Februari 2019.

Kurrotul'Aini Nurul Ma'Rifah, Implementasi Gerakan Literasi Melalui Pembiasaan Membaca Pada Siswa Di SD Muhhamadiyah Wirobrajan 3 Yogyakarta. (Yogyakarta:2017)file:///D:/TESIS\%20LITERASI\%202019/FIX\%20LITERASI\%20BAH AN/implementasi\%20gerakan\%20literasi\%20melalui\%20pembiasaan. pdf, diakses pada tanggal 26 Juni 2019

M. Azka Anfian. Implementasi Gerakan Literasi Sekolah di SMPN 06 Salatiga TahunAjaran20162017.

(Malang:2017) file://ID:/TESIS\%20LITERASI\%202019/FIX\%20LITERASI\%20BAHAN/SKRIPSI\%20F UL\%20JOZ. pdf, diakses pada tanggal 27 juni 2019

Moh. Saiful Aziz Implementasi Kultur Literasi Dalam Meningkatkan Kemampuan Membaca, Menulis, Dan Berpikir Kritis Siswa SD Plus AL Kautsar. (Salatiga: 2017) file:///D:/TESIS\%20LITERASI\%202019/FIX\%20LITERASI\%20BAHAN/implementasi\% 20kultur\%20literasi. pdf, diakses pada tanggal 28 Juni 2019. 